\title{
BANDAR NIAGA DI PERAIRAN MALUKU DAN PERDAGANGAN REMPAH-REMPAH
}

\author{
Commercial Port in the Moluccas Territorial Water and Spice Trade
}

\author{
John A. Pattikayhatu \\ Fakultas Keguruan dan Ilmu Pendidikan \\ Universitas Pattimura
}

\begin{abstract}
Abstrak
Kepulauan Maluku telah dikenal dalam jaringan perdagangan di Nusantara sejak masa lampau. Wilayah ini masuk dalam jaringan perdagangan karena merupakan sumber utama komoditi rempah-rempah khususnya cengkih dan pala. Berbagai catatan historis yang ada telah memberikan konfirmasi bahwa komoditi yang dihasilkan dari wilayah ini telah diperdagangkan hingga ke Eropa dan tempat-tempat lain di dunia. Tulisan ini membahas tentang jalur perdagangan dan pelayaran dalam konteks perdagangan rempah-rempah, bandar-bandar niaga di perairan Maluku, serta kehancuran peran perdagangan rempahrempah di Maluku.
\end{abstract}

Kata Kunci: Rempah-rempah, Bandar Niaga, Maluku, Perdagangan

\begin{abstract}
Maluku Islands are known in the trade network in the archipelago since past. These areas included in the network as the main source of commodity trading of spices, especially cloves and nutmeg. Existing historical records has confirmed that the commodities produced from this region have been trafficked to Europe and other places in the world. This paper discusses the trade and shipping in the context of the spice trade, the commercial port in the waters of the Moluccas, and the destruction of the role of the spice trade in the Moluccas.
\end{abstract}

Keywords : Spices, Commerce City, Maluku, Trade

\section{PENDAHULUAN}

Kepulauan Maluku termasuk dalam jaringan perdagangan di Nusantara sejak masa lampau. Para pedagang mancanegara telah berhubungan dengan penduduk Maluku dalam perdagangan berbagai jenis komoditi terutama rempah-rernpah (cengkih dan pala). Penduduk menanam cengkih dan pala karena mendatangkan hasil dan keuntungan yang melimpah. Adanya perdagangan rempahrempah tersebut, penduduk Maluku dapat membeli atau menukarkan dengan bahan pakaian, sutera dan porselen atau keramik.
Pelabuhan-pelabuhan seperti Hitu, Ternate dan Banda merupakan tempat penumpukan barang yang akan didistribusikan ke daerahdaerah lain di Mauku dan sebaliknya untuk mengangkut hasil dari Maluku untuk diperdagangkan ke berbagai daerah di Nusantara bagian barat sampai ke Malaka bahkan sampai ke Sulu dan Mindanau. Perahu dan kapal-kapal pengangkut barangbarang komoditi perdagangan menyinggahi pelabuhan-pelabuhan dan bandar-bandar niaga di perairan Maluku.

1. Makalah ini pernah dipresentasikan dalam Seminar Sail Banda pada tanggal 2 Agustus 2010 di Ambon dengan tema "Perairan Maluku dalam Jalur dan Jaringan Perdagangan International Masa Lampau dan Kini".

2. Guru Besar Sejarah Indonesia Baru dan Sejarah Daerah Maluku pada Universitas Pattimura 
Bagaimana keadaan bandar-bandar niaga dan perdagangan rempah-rempah tersebut dalam perjalanan sejarah akan dijelaskan dalam makalah ini dengan sistematika bahasan sebagai berikut:

1. Maluku dikenal karena penghasil rempah-rempah

2. Jalur perdagangan dan pelayaran ke Maluku

3. Tipe bandar-bandar niaga di perairan Maluku

4. Peranannya dihancurkan oleh politik monopoli Belanda

\section{MALUKU DIKENAL KARENA} REMPAH-REMPAH

Rempah-rempah hasil kepulauan Maluku seperti cengkih, pala merupakan petunjuk penting untuk mengetahui bilamana Maluku mengadakan hubungan dengan dunia luar. Menurut para ahli tumbuh-tumbuhan tanah asal dari rempah-rempah itu adalah Maluku, lebih tepat lagi pala berasal dari Maluku Tengah, dan cengkih dari Maluku Utara. Orang Tionghoa rupanya sudah mengetahui bahwa cengkih hanya dapa diambil dari Maluku.

Kitab Romawi dari Phlinius Major bahkan memuat berita rnengenai garyo phyllon, nama sebuah tanaman yang tumbuh dalam sebuah hutan sakti di India. Keteranganketerangan Philinius mengenai jenis tanama tersebut, Rouffer menarik kesimpulan bahwa yang dimaksud adalah pohon cengkih. Jika hal ini benar maka berita tersebut merupakan berita tertua yang membuktikan bahwa pada waktu itu cengkih telah dikenal di Eropa Dari berita lain bahwa St Silvester, uskup Roma dari Tahun 314-335 menerima hadiah antara lain 150 pound cengkih dan dalam tahun 547 Cosmos Indicopkustis mencata bahwa diantara barang-barang dagangan terdapat pula rernpah-rempah yang katanya didatangkan dan Tiongkok dan Sailan.

Dari berita-berita $A \boldsymbol{r a b}$ bahwa cengkih telah menjadi komoditi unggulan di negeri Arab. Ibn Khordadzbeh dalam kitabnya (844-848) mengatakan bahwa cengkih, pala, kayu cendana, kapur barus, kain tenun, gajah, merupakan bahan ekspor dari India. Daerah yang menghasilkan cengkih adalah tanah Salahit. Ibn Alfathih (902) memberitahukan bahwa rempah-rempah tersebut berasal dari Djawaja. Sedangkan Mas'udi (915-955) menyebutkan asalnya dari "Kundrang dan Le Royaume Du Maharadja, Roi Des lies Du Djawaja Et D'antres flu Dans La Mer de Chine". Penulis lain Ibrahim bin Wasifsah mengatakan bahwa cengkih berasal dari Langa sedangkan $\boldsymbol{E}$ 'drisi tahun 1154 menyebutkan bahwa hasil pulau Salahit dan daerah yang takluk kepada seorang yang bernama Maharadja. Sebuah kitab yang terbit antara 1179 - 1229 karangan Yakut Ibn Abdullah an-Rumi menyebutkan bahwa
Djawa mengekspor antara lain kayu cendana, barus, cengkih dan pala (Lapian, 1965: 68). Bersumber dari berita-benita tersebut dapat ditarik kesimpulan bahwa pelayaran ke Maluku sudah dikenal, hasil tanahnya sudah diperdagangkan di pasar internasional pada waktu itu. Namun pelayaran langsung ke Maluku belum dilaksanakan oleh pelaut-pelaut asing. Hal ini dikarenakan di sebelah barat terutama selat Malaka sudah muncul kerajaan besar yaitu Sriwijaya yang diidentikkan dengan Maharadja. Jadi hasil dari Maluku diambil di pelabuhan-pelabuhan besar di sebelah barat, terutama di selat Malaka. Pelayaran ke Maluku dilakukan oleh pedagang-pedagang lokal di Jawa maupun Maluku sendiri. Pengetahuan orang-orang Arab tentang Maluku, baru bertambah setelah Ibn Battuta seorang peneliti Arab tahun $1350 \mathrm{M}$ mencatat bahwa daerah penghasil cengkih pernah dikunjunginya. Pohon cengkih dilihatnya tumbuh dalam hutan. Dalam catatannya disebutkan cengkih yang diperdagangkan adalah batang pohonnya, sedangkan buahnya disebut pala, bunganya disebut fulli.

Selain berita-berita Arab tersebut berita yang terbit belakangan adalah berita Tionghoa yang diterjemahkan oleh Grouenevelt, bahwa Maluku untuk pertama kalinya muncul dalam sejarah raja-raja
Tang (618-906). Dikatakan pula bahwa Bali terletak disebelah timur Kaling dan disebelah barat dari "Ma-li-ki". Nama Ma$l i-k i$ ini diidentifikasikan sebagai Maluku. Sampai awal abad ke-17 semua hasil bumi dari Asia Tenggara, Sailan, India, Arab dan pantai timur Afrika digolongkan dalam berita-berita Tionghoa sebagai hasil dari Po-ssi (Persia), suatu petunjuk bahwa dalam berita-berita Tionghoa pun belum menyebut nama Maluku. Buku catatan ChuFan-Chi karangan Chau-iu-Kua tahun 1264 mengatakan bahwa cengkih adalah hasil dari San-Fo-tsi, ini diidentifikasikan sebagai Palembang/Sriwijaya, Sho-po (Jawa), Sukitan (Jawa Tengah) dan pulau Hainan. Chou-JuKua dalam kitabnya juga mejelaskan bahwa hubungan langsung antara Tionghoa dengan beberapa pelabuhan di Philipina sudah ada pada zaman ini. Begitu juga hubungan antara Tiongkok dengan Kalimantan Utara. Namun tentang cengkih dan pala tidak disebutkan dalam kitab, tetapi barang-barang tersebut diperdagangkan di pelabuhan pulau-pulau tersebut.

Hubungan langsung antara Philipina dan Maluku sudah dikenal sejak dahulu. Hal ini didukung oleh berita yang ditulis seorang Padri Spanyol kurang lebih tahun 1586 M, bahwa orang Tagalog dan Pampango telah berlayar ke luar Philipina antara lain ke Maluku. Pigafetta dalam ekspedisi mengelilingi dunia bersama Magelhaens telah berlayar sampai Mindanao. Hal ini tidak menutup kemungkinan Maluku telah dilaluinya.

\section{JALUR PERDAGANGAN DAN} PELAYARAN KE MALUKU

Faktor utama daya tarik Maluku bagi para pedagang antar bangsa adalah rempah-rempah sehingga oleh orang-orang barat Maluku dijuluki "The Spice Islands" (Kepulauan Rempah-Rempah). Raja Muslim pertama yaitu Zaenal Abidin (1486-1500) yang berkunjung kepada Prabu Zatmata di Giri, terkenal dengan julukan "Raja Bufawa" yang berarti "Raja Cengkih". Kedudukan dan peranan Maluku dengan kepulauannya seperti Ternate, Tidore, Bacan, Makyan, Ambon dan lainnya sebagai daerah rempah-rempah yang amat penting untuk mencari keuntungan dalam perdagangan bahkan pertarungan politik diantara bangsa-bangsa bara antara lain Portugis, Spanyol dan Belanda. Kepulauan Ternate dan Tidore sebelum kedatangan bangsa-bangsa barat telah terlebih dahulu didatangi orang Cina, Arab, Timur Tengah, Asia Tenggara seperti Melayu untuk melakukan perdagangan. Maluku sekita abad ke-15 sudah dicantumkan dalam berita pelayaran yaitu "Shun Feng Shiang Sung" yang merupakan pedoman untuk pelayaran yang diperkirakan oleh J. Needham berasal dan tahun $1430 \mathrm{M}$. Melalui jalur perdagangan bagian timur disebutkan berturut-turut dar Chuan-Chou ke kepulauan Pascadores lalu menyusuri Taiwan, Luzon dan Lubang ke Nindoro. Sebelah selatan dari Nindoro ada jalan lintas yang menuju Mindanau dan Maluku dari jalur pelayaran timur dilanjutkan ke Busuanga dan dari sini ada jalan pintas ke Sutu dan Donggala. Hubungan pelayara dan perdagangan antara orang-orang Muslim baik dari Arab maupun dari daerah Timur Tengah seperti Iran dan lainnya serta Gujarat, Samudra Pasai, Malaka dengan pesisi utara Jawa pada zaman Majapahit maka kemungkinan besar orang-orang Muslim itu diantaranya sudah ada yang berhubungan langsung dengan daerah Maluku.

Jaringan pelayaran dan perdagangan antara kepulauan Maluku dengan Majapahit sudah berjalan dengan baik. Pelabuhanpelabuhan yang berada di bawah kekuasaan Majapahit adalah tempat mengimpor dan mengekspor komoditi-komoditi antara lain Tuban, Gresik, Sedayu, Yaratan. Pelabuhanpelabuhan tersebut juga berfungsi untuk mengumpulkan rempah-rempah dari daerah Maluku dan Banda.

Selat Malaka menjadi salah satu trayek yang penting dan menentukan dalan sistem perdagangan Internasional yang membentang dari Cina dan Maluku di Timu sampai Afrika Timur dan Laut Tengah di 
Barat. Sistem perdagangan Indonesia melalui Malaka dihubungkan dengan jalur-jalur yang membentang ke Barat sampai India, Persia, Arabia, Syria, Afrika Timur, Laut Tengah, ke Utara sampai Siam, Pegu serta Timur sampa Cina dan Jepang. Hal ini merupakan sistem perdagangan terbesar di dunia pada masa itu. Dua pelabuhan terpenting perdagangan abad ini adalah Gujarat di India barat laut dan Malaka.

Rempah-rempah dari Maluku merupakan salah satu hasil yang paling berharga di dalam sistem ini, selain tekstil dar India dan beras dari Jawa. Malaka menjadi pusat perdagangan sedang pelabuhanpelabuhan di Sumatera sebagai tempat ekspor
Merica (Riclefs, 1990, hal 28). Malaka menjadi pusat-pusat transit perdagangan pala, cengkih, bunga pala dari Maluku ke India yang sebelumnya route itu dan Maluku ke Jawa Timur baru ke India. Sekarang kapal-kapal yang meninggalkan Jawa Timu harus singgah ke Malaka baru melanjutkan perjalanan ke India (D.G.E. HaIl, 1988: 191)

Mengenai perdagangan di Maluku, sumber-sumber asli Indonesia kurang menyinggung tentang hal itu. Dalam kitab Pararaton nama Maluku tidak disinggung dengan tegas. Hanya perkataan sumpah Gajah Mada "tidak akan memakan buah palapa selama bagian-bagian Nusantara antara lain Gorom dan Seram belum ditundukkan". Dalam kitab Negara Kartagama dikatakan bahwa Maluku, Banda, Gorom, Seram dan Ambon dimasukan daerah yang tunduk kepada Majapahit. Dan kitab-kitab tersebut meskipun hanya sedikit keberadaan Maluku telah dikenal oleh Bangsa Indonesia.

Masyarakat di Kepulauan Maluku memperdagangkan barang-barang dar luar daerah di pasar dan tiap kampung (desa) mempunyai hari pasar tertentu. Barang jualannya dibawa dalam keranjang yang disebut saloi yang diberi tali untuk digantungkan pada bahu dan punggung. Bisnis perdagangan lokal ini bisa dilakukan kaum wanita. Merekalah yang menjual dan mengadakan tawar menawar. Kalau diadakan kontrak jual beli atau jika transaksi ua anggota keluarga harus diminta pendapatnya. Menurut van Leur dalam buku "Indonesia Trade and Society", di kepulauan Indonesia seperti juga daerah lain perdagangan pantainya menjual hasil produksi yang berkualitas tinggi. Barang yans dihasilkan seperti minuman, macam-macam kayu yang mahal, hasil hutan, hasi burung-burung yang eksotik. Barang-barang dilayarkan dari luar kepulauan Indonesia. Begitu pula sebaliknya barang dilayarkan ke India atau ke Timur Tengah. Barang-barang tersebut dijual secara barter.

$$
\text { Pelabuhan-pelabuhan pusat }
$$

perdagangan di Maluku, orang-orang Cina membeli cengkih dalam jumlah besar dan uang yang digunakan sebagai alat tukar di kepulauan Maluku adalah "Fang" mata uang Cina. Menurut Galvao orang-orang Cina dianggap orang pertama yang mengadakan perdagangan di Maluku. Bahasa yang digunakan adalah bahasa Melayu yang menurut E. K. M. Masinambouw hampir sama dengan bahasa Melayu di Kalimantan Utara (E.K.M. Masinambouw. 1996: 3-4)

\section{BANDAR-BANDAR NIAGA DI} PERAIRAN MALUKU

Kepualauan Maluku terletak di tengahtengah jalur perdagangan dunia dan jaringan pelayaran yang melintasinya. Letak geografis Maluku yang didukung oleh iklim tropis telah memungkinkan datangnya para pedagang dar Eropa dan Tiongkok. Setiap setengah tahun angin berubah arahnya 180 derajat sehingga mempermudah pelayaran dalam perjalanan ke Maluku dan kembali ke negaranya. Perahu dan kapal-kapal pengangkut barangbarang komoditi perdagangan menyinggah pelabuhan-pelabuhan dan bandar-bandar niaga yang b niaga yang belada di perairan Maluku. Tipetipe bandar niaga yang sangat berperan dapa dicatat dalam proses sejarah antara lain Hitu yang merupakan bandar utama di Maluku Tengah sebelum peranan itu diambil alih oleh kota Ambon pada pertengahan abad ke-17. Dalam Hikayat Tanah Hitu dikemukakan bahwa pusat perdagangan di Hitu muncul berangsur-angsur antara tahun 1460-1490. Sebelum itu nampaknya telah ada bandarbandar niaga di berbagai tempat. Hal itu tersirat dalam kisah-kisah dari Hikayat Tanah Hitu mengenai asal usul empat penguasa Perdana Hitu yaitu di wilayah Selanbinaur yang meliputi kepulauan Seram Laut dan Gorong. Kemudian sekitar 1490 keluarga Perdana Pati Tuban muncul. Penyebutan demikian karena pernah mengunjungi Tuban dan membawa Islam ke Hitu. Sebelumnya telah ada yang berasal dari Jailolo di pulau

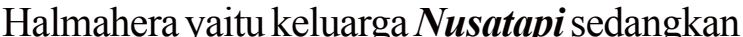
sebelumnya lagi ada yang berasal dan Jawa yatu keluarga Perdana Tanah Hitumeseng.

Hitu muncul sebagal bandar utama di Maluku Tengah sekitar awal abad ke-16 bersamaan dengan meluasnya penanaman cengkih di wilayah itu terutama di perairan Hoamual di Seram Barat. Perluasan wilayah penanaman cengkih ini ada kaitannya dengan perluasan kekuasaan Ternate di wilayah Maluku Tengah. Kedudukan istimewa Hitu

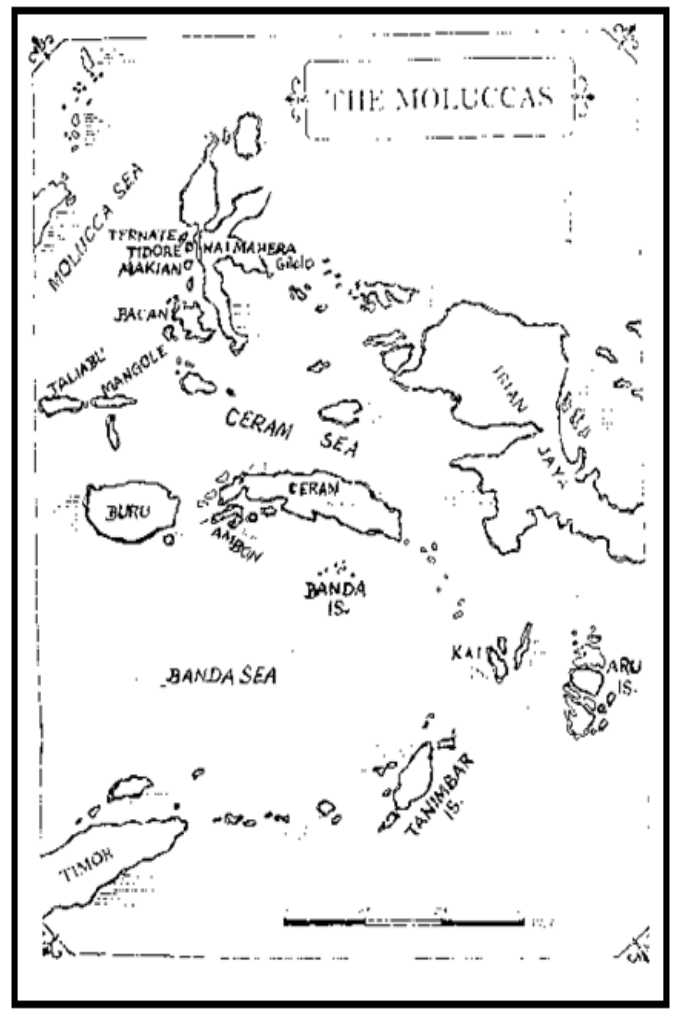

Peta Perairan Maluku disebabkan adanya hubungan dengan Jepara di Jawa. Hubungan ini terutama dibina oleh Jamilu dan turunannya yang disebut sebagal keluarga Perdana Nusatapi. Dalam Hikayat Tanah Hitu beberapa kali diceritakan mengenal pelayaran Jarmilu dan sanak keluarganya ke Jepara untuk mengadakan perdagangan dan pelayaran.

Dengan demikian, nampaknya sejak awal abad ke-16 Hitu menjadi pelabuhan utama dan pelabuhan-pelabuhan lainnya di Seram Timur dan kepulauan Serarn Laut dan Gorong mengacu pada Hitu sebagai Feeders; Karena adanya hubungan antara Seram Laut dan Gorong dengan Kepulauan Kei, Aru dan Tanimbar maka kedua gugusan pulau itupun berkaitan secara tidak langsung dengan Hitu untuk menyalurkan hasil-hasil lautnya.

Hitu mulai kehilangan posisinya sebagai bandar utama di Maluku Tengah setelah VOC menduduki benteng Portugis di Kota Laha yang kemudian dinamakan Ambon. Sejak pertengahan abad ke-17 Hitu sudah tidak begitu penting lagi. VOC menduduki lalu membangun suatu kawasan perdagangan baru yang berpusat di kota Ambon dan meliputi pulau-pulau Haruku, Saparua dan Nusalaut serta Seram Barat, wilayah yang di masa Hitu sama sekali tidak penting di lihat dari sudut perdagangan. Namun demikian, wilayah Selan Binaur dan kepulauan Seram Laut dan Gorong tetap berada di luar jangkauan. Bersama wilayah pesisir Seram Utara (negeri sembilan) sampai awal abad ke-19 wilayah ini berada di luar jangkauan kota Ambon maupun Ternate. Hubungan perdagangannya mencakup pesisir Irian Barat, kepulauan Raja Ampat ke Halmahera Timur.

Dua wilayah lainnya adalah Maluku Utara dan Maluku Tenggara kemungkinan besar sistem bandar di kedua wilayah tersebut telah ada jauh sebelum munculnya Hitu sebagai bandar niaga di Maluku Tengah. Hal ini terutarna disebabkan kedua wilayah ini merupakan produsen rempah-rempah di Maluku sebelum komoditi dagang ini juga dihasilkan di Maluku Tengah. Cengkih 
terutama dihasilkan di Maluku Utara sedangkan pala yang terbaik berasal dan kepulauan Banda.

Pola perdagangan dan bandar di kedua wilayah tersebut tidak jauh berbeda dengan pola di Maluku Tengah. Berbagai banda niaga yang telah ada kemudian memusat pada salah satu, yang karena satu dan lain sebab menjadi yang utama. Nampaknya faktor yang menyebabkan salah satu menjadi utama itu juga sama dengan di Hitu yaitu adanya hubungan dengan Jawa. Rupanya proses in berlangsung dimasa kejayaan di abad ke-14

Maluku Utara mengenal empat bandar niaga utama yaitu Jailolo, Bacan, Tidore dan Ternate. Keempat bandar niaga itu masing-masing terkait dengan sejumlah bandar lainnya di wilayah Maluku Utara Tidore umpamanya menjadi pusat dar bandar-bandar kecil disebelah timur yaitu Halmahera Timur, kepulauan Raja Empat dan pesisir Irian Barat; Ternate rnenjangkau ke barat yaitu kepulauan Banggai, pesisi Sulawesi Timur, bahkan ke Sulawesi Utara Jailolo mencakup pesisir barat Halmaher hingga awal abad ke-17, sedangkan Bacan walaupun sebelumnya mungkin lebih penting dalam masa ini hanya mencakup pulau Bacan saja. Demikian pula kepulauan Banda yang muncul pada abad ke-14. Berbagai pulau di gugusan ini terutama menghasilkan pala Di wilayah ini tidak sempat muncul sistem kekuasaan yang luas seperti di Maluku Utara dan sistem pemerintahannya mirip dengan di Hitu. Sekalipun hampir semua pulau di gugusan ini menghasilkan pala dalam jumlah besar namun bandar niaga di pulau Banda muncul sebagai pelabuhan utama. Ha ini nampaknya disebabkan para penguasa berhasil mengadakan hubungan tetap dengan pulau Jawa.

Bandar-bandar niaga sistem konvensional tersebut bertahan hingga pertengahan abad ke-17. Bahkan Portugis yang berada di wilayah itu selama hampir seratus tahun tidak berhasil merubahnya. Kisah munculnya VOC baik di Hitu maupun di Maluku Utara mengakibatkan persaingan dagang Belanda dan Portugis. Baik di Hitu maupun Ternate meminta bantuan VOC untuk melawan Portugis. Namun imbalannya adalah monopoli rempah-rempah. Ternate selanjutnya menerima dengan damai sebagai tameng terhadap Spanyol di Philipina, tetapi kemudian Hitu mengadakan perlawanan yang cukup lama hingga pertengahan abad ke-17, dengan akibat hancurnya perairan Hitu dalam dunia niaga. Berawal menguasai Hitu, VOC menghancurkan bandar-bandar niaga di seluruh kepulauan Maluku.

Dalam jangka panjang kedudukan VOC di Maluku mengubah pola banda niaga yang ada sebelumnya. Bandar niaga Ternate yang asli sebelah barat pulau Ternate ditinggalkan dan keraton Sultan dipindahkan ke lokasi yang baru dekat benteng VOC, sebelah timur pulau Ternate. Demikian pula Hitu menghilang untuk digantikan dengan kota Ambon dan selama menghilang digantikan pula oleh Banda Neira. Pusatpusat niaga VOC tersebut menjalin kaitan yang jauh berbeda dengan jaringan bandar niaga sebelurnnya. Daerah-daerah yang tidak menghasilkan rempah-rempah tidak masuk dalam jangkauan VOC, sedangkan daerahdaerah yang menghasilkan rempah-rempah seperti Ambon, Ternate dan Banda Neira berkaitan langsung dengan pusat VOC di Batavia.

\section{PENGHANCURAN PERANANNYA}

\section{OLEH VOC (BELANDA)}

Kehidupan perekonomian Maluku mulai merosot ketika bangsa Portugis dan Belanda datang pada abad ke-16 dan 17 kemudian merebut perdagangan rempahrempah. Keadaan itu terus menjadi parah ketika pemerintah kolonial Belanda mula menjalankan sistem hongi dan ekstirpasi pada akhir abad ke-18. Kebun cengkih dan pala rakyat, ditebang atau dibakar untuk rnenghindari menumpuknya hasil cengkih yang dapat berakibat turunnya harga komoditi ini di pasar Eropa. Keuntungan yans melimpah dari hasil perdagangan cengkih itu mendorong pegawai dan pejabat-pejabat
VOC menjalankan praktek korupsi dan kolusi. Akhirnya kongsi dagang itu bangkrut. Seiring dengan bangkrutnya VOC itu, pemerintah kolonial juga meninggalkan Maluku dalam keadaan miskin. Tanaman cengkih dan pala yang ditebang atau dibakar untuk mencegah merosotnya harga rempah-rempah, mengakibatkan keadaan ekonomi, sosial dan budaya masyarakt semakin merosot. t. Pada akhirnya Maluku hanya dikenang sebagai suatu mata rantai perekonomian yang hilang. Dalarn ungkapan lain disebutkan Maluku adalah masa silam.

\section{$* * * * *$}

\section{DAFTAR PUSTAKA}

Burger DhL, Prayudi, 1970. Sejarah Ekonomis Sosiologis Indonesia. Jakarta: RN Pradja Paramita.

Hall D.G.E, 1998. Sejarah Asia Tenggara (Terj) Surabaya: Usaha Nasional.

Sartono, Kartodirdjo. 1987. Pengantar Sejarah Indonesia Baru 1500-1900: Dari Emporium Sampai ke Imperium Jilid I. Jakarta: PT. Gramedia.

Lapian A.B, 1965. Beberapa Catatan Mengenal Jalan Dagang Maritim ke Maluku Utara sebelum Abad XVI. Jakarta: Majalah Ilmu-Ilmu Sastra Indonesia, Jilid 3, No. 1 (Maret) 1965.

Leur J.C. Van, 1955. Indonesian Trade and Society Essay in Asian Social and Economic History. Van Hoeve: The Hague.

Leirissa R.Z, Changing Maritime Trade Patterns in the Seram Sea dalam G.J. Schutte (ed), State and Trade in the Indonesian Archipelago. Leiden: KITLV Press.

Leirissa R.Z. 1973. Kebijaksanaan VOC untuk mendapatkan Monopoli Perdagangan Cengkih di Maluku Tengah antara Tahun 1615 dan 1652, dalam Bunga Rampai Sejarah Maluku (1). Jakarta: Lembaga Penelitian Daerah Maluku.

Leirissa R.Z, 1983. Sejarah Sosial di Daerah Maluku. Jakarta: Depdikbud.

Leirissa R.Z, 1997. Bandar-Bandar Niaga di Perairan Maluku, Makalah Diskusi Ilmiah Bandar Jalur Sutra. Jakarta.

Masinambouw E.K.M, 1996. Bahasa Ternate dalam Konteks Bahasa-Bahasa Austronesia dan Non Austronesia. Makalah dalam Diskusi Ilmiah Ternate sebagai Bandar Jalur Sutra. Ternate. 
John A. Pattikayhatu, Bandar Niaga di Perairan Maluku dan Perdagangan Rempah-Rempah

Manusama Z.J. 1973. Sekelumit Sejarah Tanah Hitu dan Nusalaut serta Struktur pemerintahannya sampai Pertengahan abad ke tujuh belas, Dalam Bunga Rampai Sejarah Maluku (1). Jakarta: Lembaga Penelitian Sejarah Maluku.

Pattikayhattu J.A., 1977. Sejarah Daerah Maluku, Proyek IDKD Dep. Pendidikan dan Kebudayaan 1976/1977. Jakarta: Departemen Pendidikan dan Kebudayaan.

Pattikayhatu J.A., 1984. Perlawanan Terhadap Imperialisme dan Kolonialisme di daerah Maluku, Departemen Pendidikan dan Kebudayaan 1983/1984. Jakarta: Departemen Pendidikan dan Kebudayaan.

Ricklefs M. C., 1993. Sejarah Indonesia Modern. Jogjakarta: Gajah Mada Press.

Hanna, Willard A. 1991. Indonesian Banda, Colonialism and Its Aftermath in the Nutmeg Islands. Yayasan Warisan dan Budaya Banda Neira. 